\title{
Correction: Managerial incentives and stock price dynamics: an experimental approach
}

\section{Te Bao $^{1}$ (D) $\cdot$ Edward Halim $^{1}$ (D) . Charles N. Noussair ${ }^{2}$ (D) Yohanes E. Riyanto $^{1}$}

Published online: 15 February 2021

(c) Economic Science Association 2021

\section{Correction to: Experimental Economics https://doi.org/10.1007/s10683-020-09675-7}

Typo error noticed by author in acknowledgement.

Grant number should be read as RG69/19 instead of RG69/16. Original article has been updated.

Publisher's Note Springer Nature remains neutral with regard to jurisdictional claims in published maps and institutional affiliations.

The original article can be found online at https://doi.org/10.1007/s10683-020-09675-7.

Charles N. Noussair

cnoussair@email.arizona.edu

1 Division of Economics, School of Social Sciences, Nanyang Technological University, Singapore, Singapore

2 Department of Economics, Eller College of Management, The University of Arizona, Tucson, USA 